\title{
METSEC PURLIN PIERCINGS, SLEEVES AND CLEATS
}

\section{Sleeved System Single Span Details \& Dimensions}

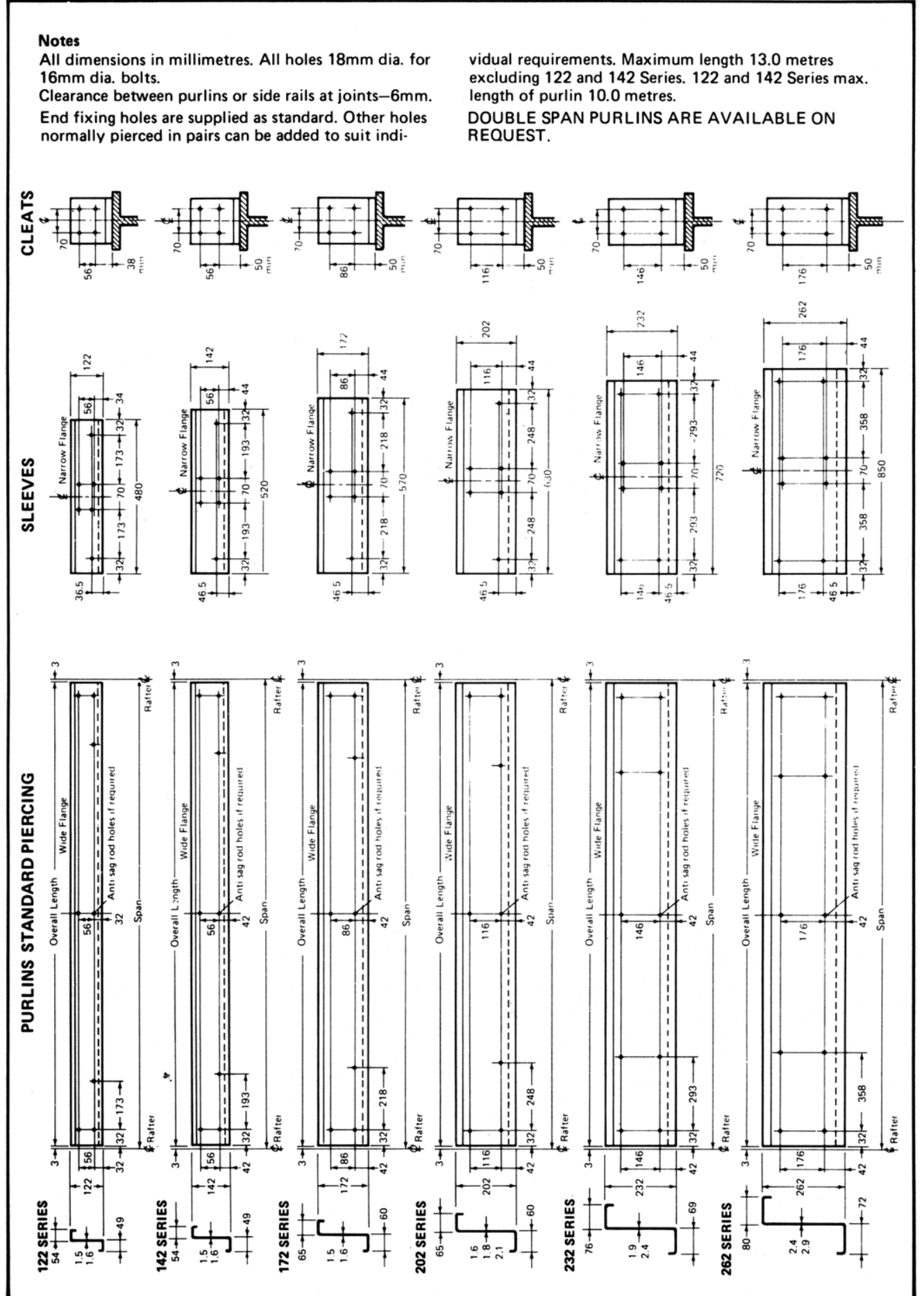

